\title{
Effect of Soaking Temperature on Physical and Functional Properties of Parboiled Rice Cultivars Grown in Temperate Region of India
}

\author{
Shabir Ahmad Mir, Sowriappan John Don Bosco* \\ Department of Food Science and Technology, Pondicherry University, Puducherry, India. \\ Email: ${ }^{*}$ sjdbosco@yahoo.com
}

Received January $2^{\text {nd }}, 2013$; revised February $2^{\text {nd }}, 2013$; accepted March $10^{\text {th }}, 2013$

\begin{abstract}
The physical and functional properties of seven parboiled rice cultivars (Jehlum, K-332, Koshar, Pusa-3, SKAU-345, SKAU-382 and SR-1) were investigated at different soaking temperatures of $60^{\circ} \mathrm{C}, 70^{\circ} \mathrm{C}$ and $80^{\circ} \mathrm{C}$ and it was compared with the brown raw rice of the respective cultivars. Parboiling was observed to decrease $\mathrm{L}^{*}$ value and increase $\mathrm{a}^{*}$ and $\mathrm{b}^{*}$ values. The hardness of rice was significantly increased after parboiling and varied among the cultivars with the highest in Jehlum. Parboiling resulted in the decrease of pasting parameters with the increase in soaking temperature from $60^{\circ} \mathrm{C}$ to $80^{\circ} \mathrm{C}$. The pasting characteristics of parboiled rice sample showed the typical behaviour having high initial viscosity, but lower peak viscosity in comparison to raw rice. The water absorption index and water solubility indices were subsequently increased with the increase in soaking temperature.
\end{abstract}

Keywords: Rice; Parboiling; Hardness; Color; Pasting Properties

\section{Introduction}

Rice parboiling is a hydrothermal process consisting of soaking, heating and drying operations modifying the qualitative and processing behaviour of rice [1,2]. Soaking is a hydration process in which the diffusion controlled water uptake migrates into the rice kernel [3] and subsequent heating leads to irreversible swelling and fusion of starch granules. The starch granules are gelatinized and retrograded as a result various changes occur in rice, which play an important role in the subsequent processing operations, such as storage, milling, cooking and in eating qualities [4].

With the spectrum of changes involved in parboiling, the quality of parboiled rice is an important aspect to examine so as to ensure that the end-quality of the product fulfils the specific preferences by specific users. Parboiled rice is harder in texture and takes longer time to cook than raw rice [5]. The proper interpretation of results of the rice processability indicators could provide a new classification of rice cultivars fulfilling food industry needs. From the industrial standpoint, it is a realistic approach to simplify rice cultivars categorization in order to control the rice quality.

Rice is an important starchy cereal crop having wider

"Corresponding author. applications for novel foods such as snack products, beverages, puddings, processed meats, salad dressings and gluten free breads [6] in addition to the cooked rice. The hydrothermal treated flour may find utility in products like soups and sauces due to low tendency to retrograde [7]. These novel foods usually require rice flours of having known functional properties, which are known to influence the characteristics of food systems [8]. The pasting profile is the most important characteristic and has been used to predict the end-use quality of various food products. On parboiling, considerable changes occur in the pasting parameters due to the order-disorder transitions taking place at the molecular level $[1,9]$.

India has different geographical areas with diverse climatic conditions. Kashmir Valley lying in northern part of India comprises the extreme western of Himalayas $\left(32.44^{\circ} \mathrm{N}\right.$ and $\left.74.54^{\circ} \mathrm{E}\right)$ and belongs to the temperate zone. The cultivation of rice extends from the area having altitude $1600 \mathrm{~m}$ above the mean sea level and grown only once in year, because of the extreme climatic conditions. Evaluation properties of parboiled rice lead to better understanding of the behaviour changes during the processing. Therefore, the objective of this investigation was to evaluate and compare the effect of parboiling on physical and functional properties of seven different rice cultivars grown in Kashmir Valley. 


\section{Materials and Methods}

\subsection{Sample Procurement}

Seven rice cultivars including Jehlum, K-332, Koshar, Pusa-3, SKAU-345, SKAU-382 and SR-1, which are prevalent in the temperate region of Kashmir Valley, were obtained from Sher-e-Kashmir University of Agriculture Science and Technology, Shalimar, Jammu and Kashmir, India. The grains were dried, cleaned manually and foreign matters such as stones, straw and dirt were removed. The dried and cleaned paddy samples were dehusked in a THU-34A Stake Testing Rice Husker (Stake, Japan) to obtain brown rice.

\subsection{Preparation of Parboiled Brown Rice}

Parboiling was done by soaking the paddy in hot water at temperatures $60^{\circ} \mathrm{C}, 70^{\circ} \mathrm{C}$ and $80^{\circ} \mathrm{C} \pm 2{ }^{\circ} \mathrm{C}$ in thermostatic water bath for 6 hours and dried in hot air oven at $40^{\circ} \mathrm{C}$. The dried and cleaned paddy samples were dehusked in a THU-34A Stake Testing Rice Husker (Stake, Japan) to obtain parboiled brown rice. A portion of each sample was ground into flour in a laboratory grain mill. The whole kernels and flour samples were stored in polypropylene pouches for further analysis.

\subsection{Hydration}

The water absorption characteristics of paddy was determined by taking $10 \mathrm{~g}$ of paddy sample of each cultivar and placed in $250 \mathrm{ml}$ of distilled water at three different soaking temperatures of $60^{\circ} \mathrm{C}, 70^{\circ} \mathrm{C}$ and $80^{\circ} \mathrm{C}$. The samples were removed at predetermined time interval of 10 min up to $3 \mathrm{hrs}$. The soaked samples were blotted with paper towels to remove residual surface moisture and then reweighed. The increase in sample mass during soaking in water was considered to be an increase in moisture content of sample.

\subsection{Color}

The color of raw and parboiled brown rice were determined by CIE color scales L*, $\mathrm{a}^{*}$ and $\mathrm{b}^{*}$ using Hunter Lab digital colorimeter (Model D25M, Hunter Associates Laboratory, Reston, VA). Where $\mathrm{L}^{*}$ indicates the degree of lightness or darkness of the sample extended from 0 (black) to 100 (white), $\mathrm{a}^{*}$ and $\mathrm{b}^{*}$ indicates degree of redness $(+a)$ to greenness $(-a)$ and whereas $b^{*}$ indicates the degree of yellowness $(+b)$ to blueness $(-b)$ respectively.

\subsection{Hardness}

Hardness of the rice grain was measured by using Texture Analyzer (TA-HD, Stable Micro Systems Ltd, Sur- rey, UK). A single compression force-versus time program was used to compress single rice grain along the thickness at a test speed of $0.10 \mathrm{~mm} / \mathrm{sec}$ and return to its original position. The original clearance between the probe and the base in load cell of the instrument was fixed at 8 $\mathrm{mm}$, so that when the probe moved down it would compress the test sample kept horizontally on the base to a distance of $0.500 \mathrm{~mm}$. program was set to move the probe at $1.0 \mathrm{~mm} / \mathrm{min}$ in both pre-test and post-test phases. A $5 \mathrm{~mm}$ diameter stainless steel probe $(\mathrm{P} / 5)$ was used to compress a single grain. The test was repeated 5 times from the same sample lot, for all the seven cultivars. The peak force indicated by the force time curve was taken as the maximum compressive force/hardness.

\subsection{Pasting Properties}

The pasting characteristic of rice flour samples was determined using Rapid Visco Analyzer (Starch master 2, Newport Scientific Pty. Ltd, Warriewood, Australia). 3 g of rice flour sample (13 g/100g moisture basis) was weighed in RVA canister and $25 \mathrm{ml}$ of water was added. The prepared slurry in the canister was heated to $50^{\circ} \mathrm{C}$ and stirred at $160 \mathrm{rpm}$ for $10 \mathrm{~s}$ to enable the complete dispersion. The slurry was held to $50^{\circ} \mathrm{C}$ for $1 \mathrm{~min}$ and temperature was raised to $95^{\circ} \mathrm{C}$ over $7.5 \mathrm{~min}$. and then held at $95{ }^{\circ} \mathrm{C}$ for $5 \mathrm{~min}$. The slurry was then cooled at $50^{\circ} \mathrm{C}$ in $7.5 \mathrm{~min}$, and then held at $50^{\circ} \mathrm{C}$ for $2 \mathrm{~min}$. Pasting parameters including peak viscosity (PV), viscosity at the end of hold time at $95^{\circ} \mathrm{C}$ or hot paste viscosity (HPV), final viscosity (FV) at the end of cooling, breakdown $(\mathrm{BD}=\mathrm{PV}-\mathrm{HPV})$, setback $(\mathrm{SB}=\mathrm{FV}-\mathrm{HPV})$ and pasting temperature were recorded.

\subsection{Water Absorption Index (WAI) and Water Solubility (WS)}

For the measurement of WAI, $2.5 \mathrm{~g}$ of flour sample was suspended in $30 \mathrm{ml}$ distilled water in previously weighed $50 \mathrm{ml}$ centrifuge tube, stirred intermittently over a 30 min period at $30^{\circ} \mathrm{C}$ and then centrifuged at $3000 \mathrm{~g}$ for 10 min. After pouring the supernatant into a tarred evaporating dish the gel was weighed. The WS was determined from the amount of dry sample weight recovered by evaporating the supernatant from flour water absorption experiment.

$$
\begin{aligned}
& \text { Water absorption index }=\frac{\text { Wet sediment weight }}{\text { Dry sediment weight }} \\
& \text { Water solubility }=\frac{\text { Dry supernatent weight }}{\text { Dry sample weight }} \times 100
\end{aligned}
$$

\subsection{Statistical Analysis}

The date reported in all the tables is the average value of 
three replications. The data were analyzed statistically using SPSS software (SPSS PASW 18.0) and the means were separated using the Duncan's multiple range test (P $\leq 0.05)$.

\section{Result and Discussion}

\subsection{Hydration}

The water uptake content of varieties of paddy throughout soaking at each of $60^{\circ} \mathrm{C}, 70^{\circ} \mathrm{C}$ and $80^{\circ} \mathrm{C}$ for 3 hours at 10 minutes intervals is depicted in Figure 1. The rate of water absorption was dependent on the temperature and time of soaking. Higher the parboiling temperature, higher the rate of water absorption was observed with the similar pattern of hydration curves. For soaking at $60^{\circ} \mathrm{C}$, the curves exhibited the typical moisture absorption behaviour with the rate of water absorption was initially high followed by the slower absorption in later stages.

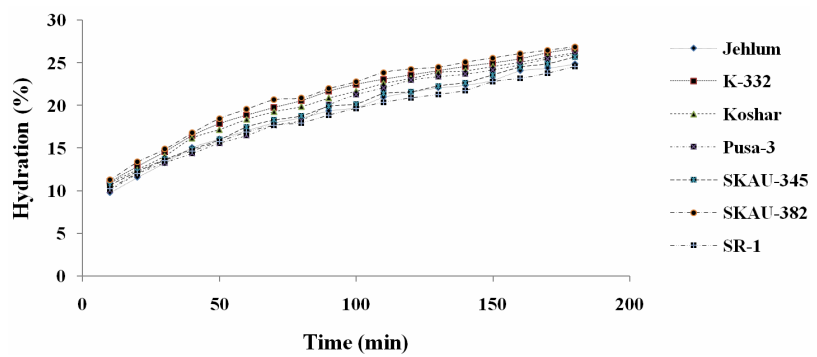

(a)

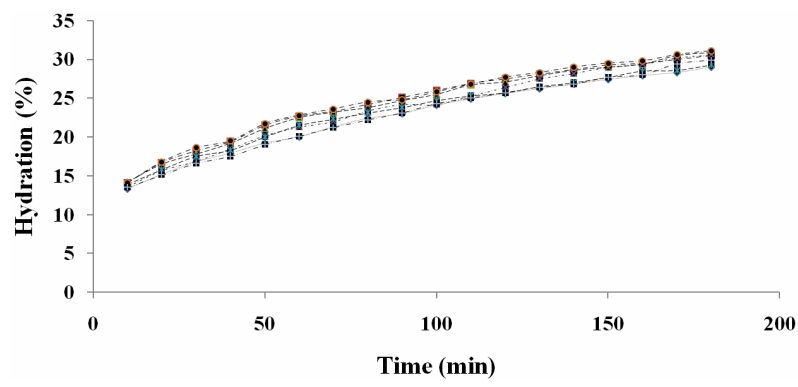

(b)

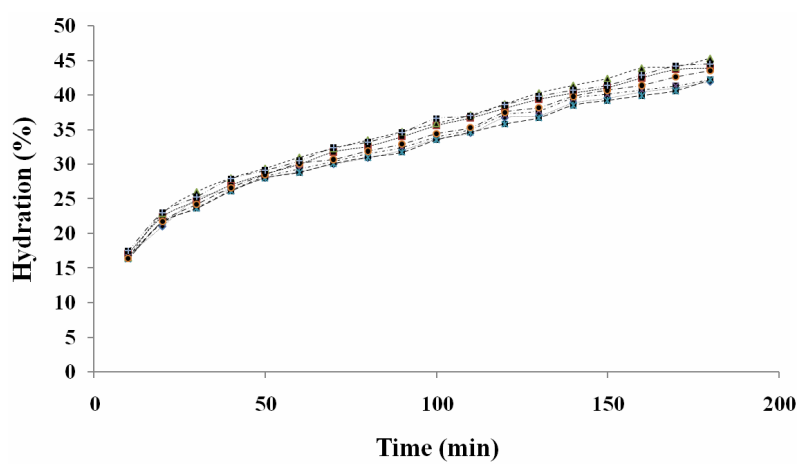

(c)

Figure 1. Hydration curve for paddy cultivars at (a) $60^{\circ} \mathrm{C}$; (b) $70^{\circ} \mathrm{C}$; (c) $80^{\circ} \mathrm{C}$.
However, the soaking at $70^{\circ} \mathrm{C}$ and $80^{\circ} \mathrm{C}$ showed a rapid increase in the hydration rate. Such an increase might be due to the irreversible changes that occur in the starch granules as a result of the gelatinization process. Among varieties of cultivars, K-332, Koshar and Pusa-3 were swelled considerably at $80^{\circ} \mathrm{C}$ and showed the disrupted structure with the breaking of hull of kernels, which enhanced the absorption rate. An increase in the turbidity of soaking water was observed in some rice samples at $80^{\circ} \mathrm{C}$ due to the release of part of the endosperm components. The variety difference in water absorption s may be due to the differences in their microstructure [10]. The observation of variety difference in water absorption in the present study could be supported by the variation among Gallo, RP2 and PR116 varieties [11,12].

\subsection{Color}

Figure 2 shows the changes in the color of parboiled rice

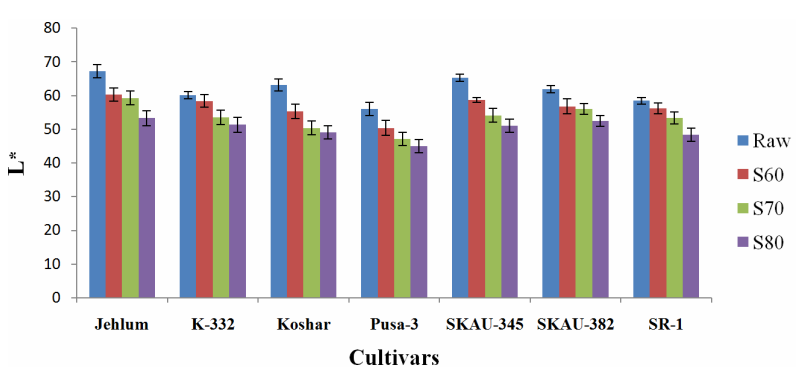

(a)

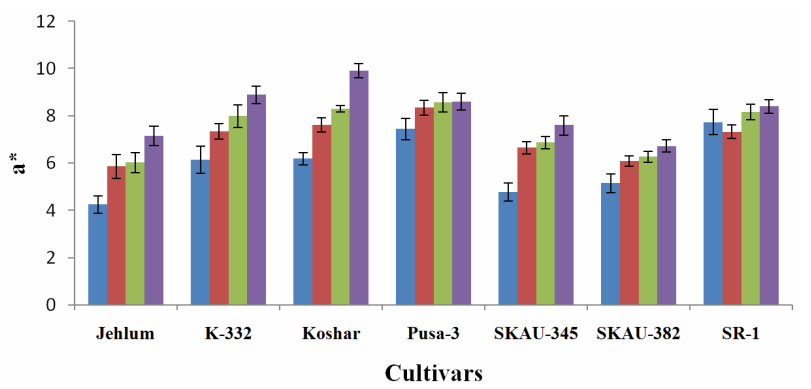

(b)

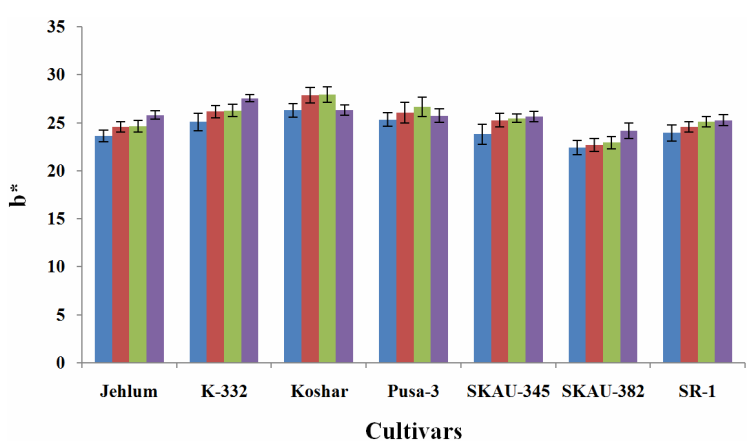

(c)

Figure 2. Color values of raw and parboiled rice cultivars ( $\mathrm{L}^{*}, \mathrm{a}^{*}$ and $\mathrm{b}^{*}$ ). 
of different cultivars in comparison to the color of raw brown rice as described in terms of $\mathrm{L}^{*}, \mathrm{a}^{*}$ and $\mathrm{b}^{*}$ values. There was a significant varietal difference in the color of raw brown rice kernels of different cultivars as $L^{*}$ value was observed to be higher in Jehlum and lower in Pusa-3 followed by SR-1, whereas a* value was higher for SR-1 (7.73) and lower for Jehlum (4.23) and $b^{*}$ value was higher for Koshar (26.29) and lower in SKAU-382 (22.41). The difference in color among variety of rice cultivars could be attributed to the difference in genetic makeup, colored pigments and composition of flour [2,13,14]. The effect of parboiling with the increase in temperature during soaking was observed to decrease the lightness $\left(\mathrm{L}^{*}\right)$ and increase the redness $\left(a^{*}\right)$ and yellowness $\left(b^{*}\right)$ of brown rice of different varieties as reported in earlier literature [15]. However, Koshar and Pusa-3 were observed to have decreased $\mathrm{b}^{*}$ at $80^{\circ} \mathrm{C}$ of parboiling treatment. Islam et al. [16] also reported that the lightness of parboiled rice was mainly affected by the temperature and the decreasing tendency was more at higher temperature. The color change in rice grain is mainly caused by maillard reaction, diffusion of husk pigments in the endosperm during soaking and processing conditions in parboiling which determines the intensity of color [1].

\subsection{Hardness}

Parboiling process results in a less insect infested product and imparts hardening of the grains, which makes them more resistant to breakage during milling. This in turn leads to an increased yield, giving an economic advantage to the process $[16,17]$. Figure 3 depicts the significant increase in the hardness of different rice cultivars steeped at $60^{\circ} \mathrm{C}, 70^{\circ} \mathrm{C}$ and $80^{\circ} \mathrm{C}$ of parboiling process as compared to the hardness of their raw rice samples. Jehlum, which had the highest hardness (131.41 N) among raw rice of different cultivars, was observed to have the hardness increased to (163.71), and (177.79), (185.80 N) with the increase in the temperature of soaking at $60^{\circ} \mathrm{C}$, $70^{\circ} \mathrm{C}, 80^{\circ} \mathrm{C}$ respectively. Similarly the lowest hardness found in the raw rice of both the Koshar and K-332 cul-

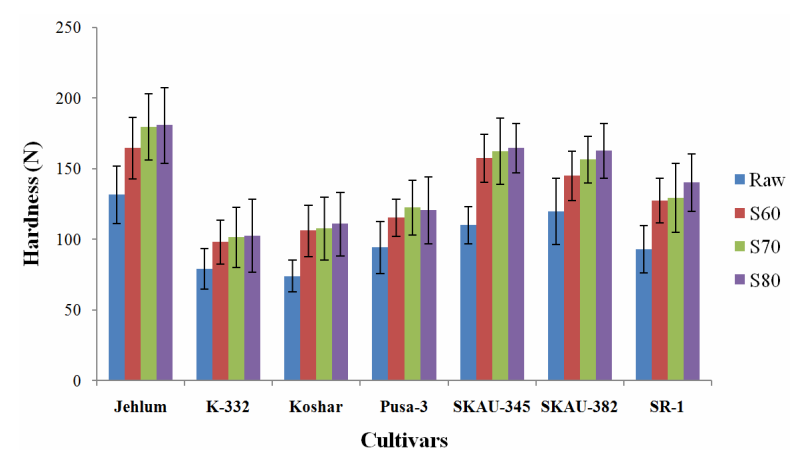

Figure 3. Hardness of raw and parboiled rice cultivars. tivars, was increased with the effect of parboiling comparable to each other $(\mathrm{P} \leq 0.05)$. The variety difference in the hardness of rice grains is due to the difference in the compact arrangement of starch granules among rice cultivars. The hardness in parboiled rice imparted to kernels is accountable to the gelatinization process of starch and adhesion between starch granules and protein bodies. The swelling of starch completely heals the cracks and chalkiness of rice grain and improve its hardness [18].

\subsection{Pasting Properties}

The effect of soaking temperature $\left(60^{\circ} \mathrm{C}, 70^{\circ} \mathrm{C}\right.$ and $\left.80^{\circ} \mathrm{C}\right)$ on pasting properties determined by Rapid Visco Analyzer (RVA) is depicted in Figure 4. When compared to the pasting profile of raw rice from different cultivars, parboiling was observed to decrease the pasting profile of samples resulting from the increase in damaged starch to absorb the water content and decreased peak viscosity resulting from the resistance of starch granules for swelling due to the gelatinisation process takes place in parboiling.

Raw sample of Jehlum showed the highest pasting profile as compared to raw rice of other cultivars as shown in Figure 4 with the highest peak viscosity (3373 cP), final viscosity $(6662 \mathrm{cP})$ and setback viscosity (3389 cP) among the seven cultivars. When a sufficient number of starch granules become swollen, a rapid increase in viscosity occur known as peak viscosity. The peak Viscosity is decreased among all the cultivars with subsequent increase of soaking temperatures predominantly in Pusa-3 and Koshar. The extensive thermal breakdown of the starch in the parboiled sample may have caused the very low viscosity values. Pasting profile of flour has been found to be influenced by its starch [19], protein [20], lipid [21] contents and the degree of starch damage during processing $[22,23]$.

The setback values indicate the hardness of gel paste upon cooling [24], which is indirect measurement of retrogradation of starches [20]. The highest setback values of raw rice were found in Jehlum cultivar (3289 cP), where it decreased drastically to $1090 \mathrm{cP}$ at $80^{\circ} \mathrm{C}$. Low setback viscosity values of hydrothermally treated flour samples indicated lesser tendency to retrograde or syneresis upon cooling.

Breakdown viscosity, measure of the ease with which the swollen granules can be disintegrated. Higher breakdown viscosity in starches can be attributed to higher crystallinity and lower amylose content [25]. For raw rice, the highest holding viscosity were observed in SKAU345 (2683 cP), whereas the lowest was in Pusa-3 (1483 cP). However, the breakdown viscosity ranged from 742 $\mathrm{cP}(\mathrm{K}-332)$ to $149 \mathrm{cP}$ in Pusa-3. The breakdown viscosity decreased considerably with parboiling temperature with 

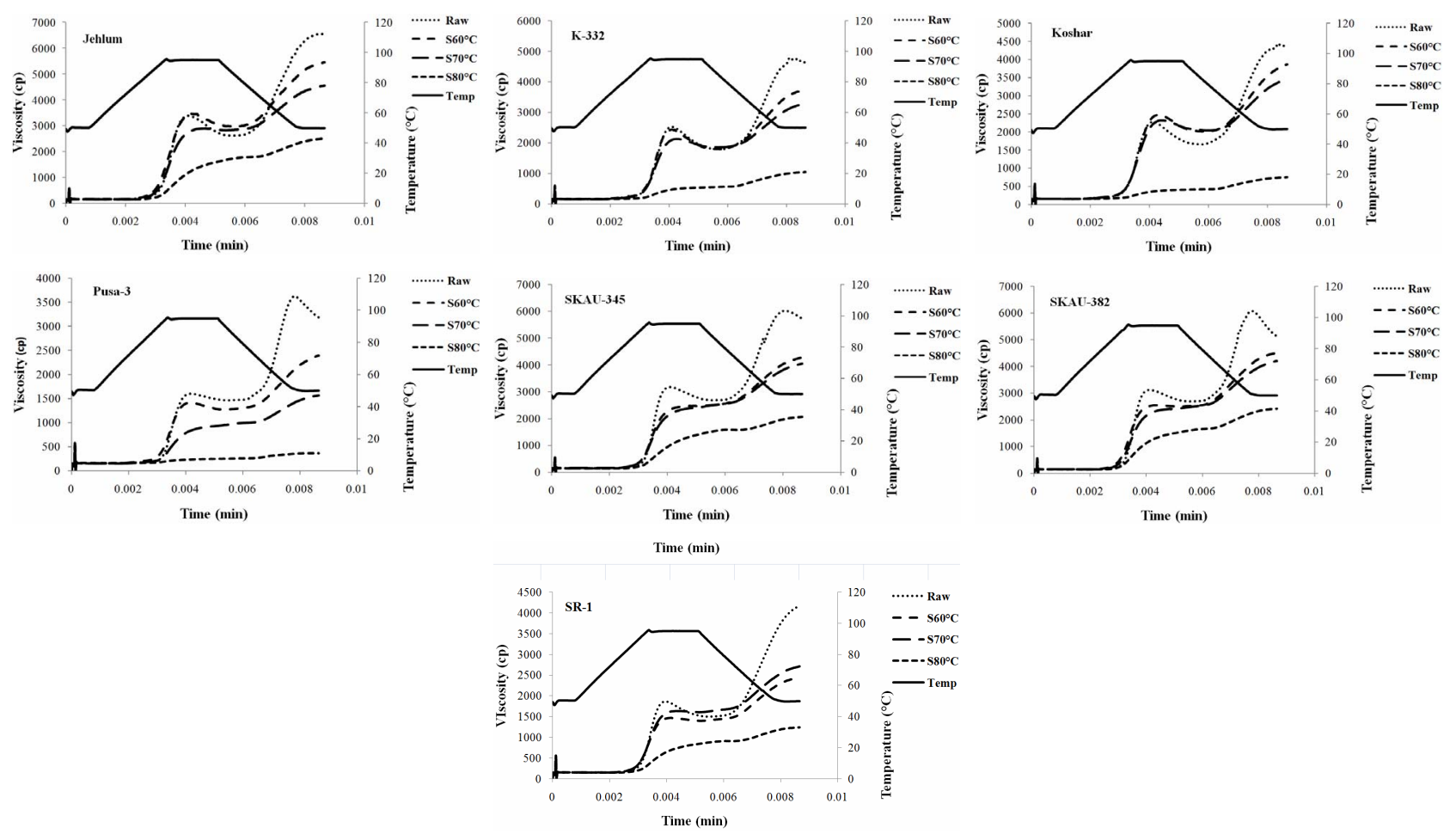

Figure 4. Pasting properties of raw and parboiled rice samples.

the lowest $(2 \mathrm{cP})$ in the cultivar Pusa- 3 at $80^{\circ} \mathrm{C}$. The decrease of breakdown viscosity might be due to the failure of complete pasting and swelling of starch granules induced by the reduction of water absorption of starch granules [1]. The pasting temperature increased with increase in parboiling treatments. The higher parboiling treatment causes the increase in pasting temperature with processing as reported by previous workers [26].

\subsection{Waster Absorption Index and Water Solubility}

Water absorption characteristics represent the ability of a sample to reassociate with water under conditions where water is limiting $[14,27]$. The variation in WAI and WS among different rice cultivars are depicted in Table 1. The results indicated the variety difference in WAI ranging from 21.5 in Jehlum to $2.41 \%$ in Pusa-3 for raw rice samples and found to be increased to $3.52 \%$ and $4.68 \%$ at $60^{\circ} \mathrm{C}, 3.68 \%$ and $4.60 \%$ at $70^{\circ} \mathrm{C}$ and $4.01 \%$ to $5.92 \%$ at $80^{\circ} \mathrm{C}$ for parboiled Jehlum and Pusa-3 respectively. This might be due to the more damaged starch present in parboiled rice flour at different temperatures to imbibe and hold more water.

However, after parboiling the solubility was also enhanced in all rice cultivars. Water solubility of raw rice flour samples of different rice cultivars ranging from 1.50 to 2.60 was found to be varied from 2.44 to 3.85 at
Table 1. Water absorption index (WAI) and water solubility (WS) of raw and parboiled rice samples.

\begin{tabular}{|c|c|c|c|}
\hline Cultivars & Treatment & WAI & WS \\
\hline \multirow{4}{*}{ Jehlum } & Raw & $2.15 \pm 0.12^{\mathrm{k}}$ & $1.50 \pm 0.14^{\mathrm{f}}$ \\
\hline & $\mathrm{S} 60^{\circ} \mathrm{C}$ & $4.05 \pm 0.27^{\mathrm{efg}}$ & $2.33 \pm 0.26^{\mathrm{de}}$ \\
\hline & $\mathrm{S} 70^{\circ} \mathrm{C}$ & $4.16 \pm 0.33^{\text {cdefg }}$ & $2.37 \pm 0.21^{\mathrm{de}}$ \\
\hline & $\mathrm{S} 80^{\circ} \mathrm{C}$ & $4.92 \pm 0.31^{\mathrm{b}}$ & $2.44 \pm 0.14^{\mathrm{de}}$ \\
\hline \multirow{4}{*}{$\mathrm{K}-332$} & Raw & $2.52 \pm 0.21^{\mathrm{ijk}}$ & $2.38 \pm 0.25^{\mathrm{de}}$ \\
\hline & $\mathrm{S} 60^{\circ} \mathrm{C}$ & $4.52 \pm 0.41^{\mathrm{bcde}}$ & $3.52 \pm 0.17^{\mathrm{de}}$ \\
\hline & $\mathrm{S} 70^{\circ} \mathrm{C}$ & $4.60 \pm 0.15^{\mathrm{bcd}}$ & $3.64 \pm 0.29^{\mathrm{a}}$ \\
\hline & $\mathrm{S} 80^{\circ} \mathrm{C}$ & $5.88 \pm 0.38^{\mathrm{a}}$ & $3.85 \pm 0.25^{\mathrm{a}}$ \\
\hline \multirow{4}{*}{ Koshar } & Raw & $2.99 \pm 0.13 \mathrm{j}$ & $2.59 \pm 0.21^{\mathrm{cde}}$ \\
\hline & $\mathrm{S} 60^{\circ} \mathrm{C}$ & $4.42 \pm 0.15^{\text {bcdef }}$ & $2.52 \pm 0.21^{\mathrm{de}}$ \\
\hline & $\mathrm{S} 70^{\circ} \mathrm{C}$ & $4.45 \pm 0.23^{\text {bcdef }}$ & $2.52 \pm 0.11^{\mathrm{de}}$ \\
\hline & $\mathrm{S} 80^{\circ} \mathrm{C}$ & $5.93 \pm 0.46^{\mathrm{a}}$ & $2.92 \pm 0.22^{\mathrm{bc}}$ \\
\hline \multirow{4}{*}{ Pusa-3 } & Raw & $3.01 \pm 0.21^{\mathrm{i}}$ & $2.23 \pm 0.19^{\mathrm{e}}$ \\
\hline & $\mathrm{S} 60^{\circ} \mathrm{C}$ & $4.66 \pm 0.33^{b c}$ & $3.15 \pm 0.15^{\mathrm{b}}$ \\
\hline & $\mathrm{S} 70^{\circ} \mathrm{C}$ & $4.79 \pm 0.20^{b}$ & $3.18 \pm 0.18^{\mathrm{b}}$ \\
\hline & $\mathrm{S} 80^{\circ} \mathrm{C}$ & $5.59 \pm 0.43^{\mathrm{a}}$ & $3.66 \pm 0.26^{\mathrm{a}}$ \\
\hline \multirow{4}{*}{ SKAU-345 } & Raw & $2.62 \pm 0.13^{\mathrm{ijk}}$ & $2.48 \pm 0.11^{\mathrm{de}}$ \\
\hline & $\mathrm{S} 60^{\circ} \mathrm{C}$ & $3.67 \pm 0.30^{\mathrm{gh}}$ & $2.47 \pm 0.08^{\mathrm{de}}$ \\
\hline & $\mathrm{S} 70^{\circ} \mathrm{C}$ & $3.98 \pm 0.43^{\mathrm{fgh}}$ & $2.53 \pm 0.22^{\mathrm{de}}$ \\
\hline & $\mathrm{S} 80^{\circ} \mathrm{C}$ & $4.43 \pm 0.26^{\text {bcdef }}$ & $2.64 \pm 0.14^{\mathrm{cd}}$ \\
\hline \multirow{4}{*}{ SKAU-382 } & Raw & $2.87 \pm 0.17^{\mathrm{ij}}$ & $1.77 \pm 0.23^{\mathrm{f}}$ \\
\hline & $\mathrm{S} 60^{\circ} \mathrm{C}$ & $3.52 \pm 0.11^{\mathrm{h}}$ & $2.43 \pm 0.30^{\mathrm{de}}$ \\
\hline & $\mathrm{S} 70^{\circ} \mathrm{C}$ & $3.66 \pm 0.31^{\mathrm{gh}}$ & $2.50 \pm 0.25^{\mathrm{de}}$ \\
\hline & $\mathrm{S} 80^{\circ} \mathrm{C}$ & $4.04 \pm 0.22^{\mathrm{efg}}$ & $2.53 \pm 0.13^{\mathrm{a}}$ \\
\hline \multirow{4}{*}{ SR-1 } & Raw & $2.41 \pm 0.21^{\mathrm{jk}}$ & $2.57 \pm 0.18^{\mathrm{de}}$ \\
\hline & $\mathrm{S} 60^{\circ} \mathrm{C}$ & $4.12 \pm 0.23^{\mathrm{defg}}$ & $3.58 \pm 0.20^{\mathrm{a}}$ \\
\hline & $\mathrm{S} 70^{\circ} \mathrm{C}$ & $4.23 \pm 0.22^{\text {cdef }}$ & $3.61 \pm 0.20^{\mathrm{a}}$ \\
\hline & $\mathrm{S} 80^{\circ} \mathrm{C}$ & $4.47 \pm 0.45^{\text {bcdef }}$ & $3.81 \pm 0.21^{\mathrm{b}}$ \\
\hline
\end{tabular}

Values are expressed as mean \pm standard deviation. Means having different letters with in the same column differ significantly at $\mathrm{P} \leq 0.05(\mathrm{n}=5)$. 
$80^{\circ} \mathrm{C}$ of parboiling as solubility behaviour is highly improved by various cooking treatment [28]. WAI and WS were found increased due to the effect of parboiling in the present study could be supported by the observations of various cereal flours with an enhanced WAI, WS during different processing conditions as shown in literature $[29,30]$, and the variation in raw flours of different rice cultivars could be attributed to the varietal diversity in different cultivars [13,14].

\section{Conclusion}

The study explored the effect of different soaking temperatures on physical and functional properties of rice cultivars. These changes differ by cultivars and subsequent parboiled conditions. Color values showed the variation among the cultivars and darkness was increased with the increase of soaking temperature. Higher soaking temperatures increased the hardness value which will help to increase the milling yield of rice. Pasting property of rice samples substantially decreased by parboiling with severe decrease at $80^{\circ} \mathrm{C}$. Changes in water absorption index and water solubility properties were pronounced at different parboiling temperatures, which can be exploited in new product development application.

\section{REFERENCES}

[1] H. Dutta and C. L. Mahanta, "Effect of Hydrothermal Treatment Varying in Time and Pressure on the Properties of the Parboiled Rices with Different Amylose Content," Food Research International, Vol. 49, No. 2, 2012, pp. 655-663. doi:10.1016/j.foodres.2012.09.014

[2] T. A. Shittu, M. B. Olaniyi, A. A. Oyekanmi and K. A. Okeleye, "Physical and Water Absorption Characteristics of Some Improved Rice Varieties," Food Bioprocess Technology, Vol. 5, No. 1, 2012, pp. 298-309. doi:10.1007/s11947-009-0288-6

[3] S. D. Deshpande, S. Bal and T. P. Ojha, "A Study on Diffusion of Water by the Soybean during Cold Water Soaking," Journal of Food Engineering, Vol. 23, No. 1, 1994, pp. 121-127. doi:10.1016/0260-8774(94)90127-9

[4] J. Patindol, J. Newton and Y. J. Wang, "Functional Properties as Affected by Laboratory Scale Parboiling of Rough Rice and Brown Rice," Journal of Food Science, Vol. 73, No. 8, 2008, pp. 370-377. doi:10.1111/j.1750-3841.2008.00926.x

[5] K. R. Bhattacharya, "Chapter 13: Parboiling of Rice," In: T. Elaine, Ed., Rice Chemistry and Technology, American Association of Cereal Chemists, Inc., St. Paul, 2004, pp. 329-394. doi:10.1094/1891127349.013

[6] R. S. Kadan, R. J. Byrant and J. A. Miller, "Effects of Milling on Functional Properties of Rice Flour," Food engineering and Physical Properties, Vol. 73, No. 4, 2008, pp. 151-154.

[7] K. O. Adebowale and O. S. Lawal, "Functional Properties and Retrogradation Behaviour of Native and Chemically Modified Starch of Mucuna Bean (Mucuna pruriens)," Journal of the Science of Food and Agriculture, Vol. 83, No. 15, 2003, pp. 1541-1546. doi:10.1002/jsfa.1569

[8] M. Kaur and N. Singh, "Studies on Functional, Thermal and Pasting Properties of Flours from Different Chickpea (Cicer arietinum L.) Cultivars," Food Chemistry, Vol. 93, No. 3, 2005, pp. 403-411.

doi:10.1016/j.foodchem.2004.06.015

[9] L.-J. Zhu, Q.-Q. Liu, Y. J. Sang, M.-H. Gu and Y.-C. Shi, "Underlying Reasons for Waxy Rice Flours Having Different Pasting Properties," Food Chemistry, Vol. 120, No. 1, 2010, pp. 94-100. doi:10.1016/j.foodchem.2009.09.076

[10] H. H. Chen, Y. K. Chen and H. C. Chang, "Evaluation of Physicochemical Properties of Plasma Treated Brown Rice," Food Chemistry, Vol. 135, No. 1, 2012, pp. 74-79. doi:10.1016/j.foodchem.2012.04.092

[11] M. Bello, M. P. Tolaba and C. Suarez, "Factors Affecting Water Uptake of Rice Grain during Soaking," LWT Food Science and Technology, Vol. 37, No. 8, 2004, pp. 811816. doi:10.1016/i.lwt.2004.02.014

[12] A. K. Thakur and A. K. Gupta, "Water Absorption Characteristics of Paddy, Brown Rice and Husk during Soaking," Journal of Food Engineering, Vol. 75, No. 2, 2006 , pp. 252-257. doi:10.1016/j.jfoodeng.2005.04.014

[13] N. Y. N. Aboubakar, J. Scher and C. M. F. Mbofung, "Physicochemical, Thermal Properties and Micro Structure of Six Varieties of Taro (Colocasia esculenta L. Schott) Flours and Starches," Journal of Food Engineering, Vol. 86, No. 2, 2008, pp. 294-305. doi:10.1016/j.jfoodeng.2007.10.006

[14] M. Kaur, P. Kaushal and K. S. Sandhu, "Studies on Physicochemical and Pasting Properties of Taro (Colocasia esculenta L.) Flour in Comparison with a Cereal, Tuber and Legume Flour," Journal of Food Science and Technology, Vol. 50, No. 1. 2011, 94-100. doi:10.1007/s13197-010-0227-6

[15] L. Lamberts, E. De Bie, V. Derycke, W. S. Veraverbeke, W. De Man and J. A. Delcour, "Impact of Browning Reactions and Bran Pigments on Color of Parboiled Rice," Journal of Agricultural and Food Chemistry, Vol. 54, No. 26, 2006, pp. 9924-9929. doi:10.1021/jf062140j

[16] M. R. Islam, N. Shimizu and T. Kimura, "Energy Requirement in Parboiling and Its Relationship to Some Important Quality Indicators," Journal of Food Engineering, Vol. 63, No. 4, 2004, pp. 433-439. doi:10.1016/j.jfoodeng.2003.09.002

[17] B. Juliano and D. Bechtel, "The Rice Grain and Its Gross Composition," In: B. Juliano, Ed., Rice Chemistry and Technology, 2nd Edition, American Association of Cereal Chemists, St. Paul, 1985, pp. 17-58.

[18] K. M. Sahay and K. K. Singh, "Unit Operations of Agricultural Processing," Vikas Publishing House Pvt. Ltd., New Delhi, 1994.

[19] S. Ragaee and E. M. Abdel-Aal, "Pasting Properties of Starch and Protein in Selected Cereals and Quality of Their Food Products," Food Chemistry, Vol. 95, No. 1, 2006, pp. 9-18. doi:10.1016/j.foodchem.2004.12.012 
[20] I. S. M. Zaidul, N. A. N. Norulaini, A. K. M. Omar, H. Yamauchi and T. Noda, "RVA Analysis of Mixtures of Wheat Flour and Potato, Sweet Potato, Yam and Cassava Starches," Carbohydrate Polymer, Vol. 69, No. 2, 2007, pp. 784-791. doi:10.1016/j.carbpol.2007.02.021

[21] P. L. Russell, "The Aging of Gels from Starches of Different Amylose/Amylopectin Content Studied by Differential Scanning Calorimetry," Journal of Cereal Science, Vol. 6, No. 2, 1987, pp. 147-158. doi:10.1016/S0733-5210(87)80051-6

[22] T. O. Osungbaro, "Effect of Fermentation Period on Amylose Content and Textural Characteristics of "Ogi" (A Fermented Maize Porridge)," Journal of Fermentation and Bioengineering, Vol. 70, No. 1, 1990, pp. 22-25. doi:10.1016/0922-338X(90)90024-Q

[23] M. O. Onitilo, L. O. Sanni, I. Daniel, B. Maziya-Dixon and A. Dixon, "Physicochemical and Functional Properties of Native Starches from Cassava Varieties in Southwest Nigeria," Journal of Food, Agriculture and Environment, Vol. 5, No. 3, 2007, pp. 108-114.

[24] I. Lee, G. Y. We, D. E. Kim, Y. S. Cho, M. R. Yoon, M. Shin and S. Ko, "Classification of Rice Cultivars Based on Cluster Analysis of Hydration and Pasting Properties of Their Starches," LWT-Food Science and Technology, Vol. 48, No. 2, 2012, pp. 164-168. doi:10.1016/j.lwt.2012.03.002

[25] N. Singh, N. Inouchi and K. Nishinari, "Structural, Ther- mal and Viscoelastic Characteristics of Starches Separated from Normal, Sugary and Waxy Maize," Food Hydrocolloids, Vol. 20, No. 6, 2006, pp. 923-935. doi:10.1016/j.foodhyd.2005.09.009

[26] T. Swasdisevi, W. Sriariyakula, W. Tia and S. Soponronnarit, "Effect of Pre-Steaming on Production of Partially Parboiled Using Hot Air Fluidization Technique," Journal of Food Engineering, Vol. 96, No. 3, 2010, pp. 455462. doi:10.1016/j.jfoodeng.2009.08.026

[27] U. Singh, "Functional Properties of Grain Legume Flours," Journal of Food Science and Technology, Vol. 38, No. 3, 2001, pp. 191-199.

[28] D. Jones, R. Chinnaswamy, Y. Tan and M. Hanna, "Physiochemical Properties of Ready-to-Eat Breakfast Cereals," Cereal Foods World, Vol. 45, No. 4, 2000, pp. 164168.

[29] M. Mariotti, C. Alamprese, M. A. Pagani and M. Lucisano, "Effect of Puffing on Ultrastructure and Physical Characteristics of Cereal Grains and Flours," Journal of Cereal Science, Vol. 43, No. 1, 2006, pp. 47-56. doi:10.1016/i.jcs.2005.06.007

[30] B. K. Baik, J. Powers and L. T. Nguyen, "Extrusion of Regular and Waxy Barley Flours for Production of Expanded Cereals," Cereal Chemistry, Vol. 81, No. 1, 2004, pp. 94-99. doi:10.1094/CCHEM.2004.81.1.94 